Please do not remove this page

RMIT

UNIVERSITY

\title{
Deleuzian dragons: Thinking Chinese strategic spatial planning with Gilles Deleuze
}

Hillier, Jean; Cao, Kang

https://researchrepository.rmit.edu.au/esploro/outputs/9921859113701341/filesAndLinks?institution=61RMIT_INST\&index=null

Hillier, J., \& Cao, K. (2013). Deleuzian dragons: Thinking Chinese strategic spatial planning with Gilles Deleuze. Deleuze Studies, 7(3), 390-405. https://doi.org/10.3366/dls.2013.0119

Document Version: Published Version

Published Version: https://doi.org/10.3366/dls.2013.0119

Repository homepage: https://researchrepository.rmit.edu.au

(c) Edinburgh University Press

Downloaded On 2023/04/26 23:57:06 +1000

Please do not remove this page 
Thank you for downloading this document from the RMIT Research Repository.

The RMIT Research Repository is an open access database showcasing the research outputs of RMIT University researchers.

RMIT Research Repository: http://researchbank.rmit.edu.au/

\section{Citation:}

Deleuzian dragons: Thinking Chinese strategic spatial planning with Gilles Deleuze Hillier, J and Cao, K 2013, 'Deleuzian dragons: Thinking Chinese strategic spatial planning with Gilles Deleuze', Deleuze Studies, vol. 7, no. 3, pp. 390-405.

See this record in the RMIT Research Repository at:

https://researchbank.rmit.edu.au/view/rmit:21990

Version: Published Version

Copyright Statement: (c) Edinburgh University Press

Link to Published Version:

http://dx.doi.org/10.3366/dls.2013.0119 


\title{
Deleuzian Dragons: Thinking Chinese Strategic Spatial Planning with Gilles Deleuze
}

\author{
Jean Hillier RMIT University \\ Kang Cao Zhejiang University
}

\begin{abstract}
As symbols of adaptability and transformation, together with qualities of vigilance and intelligence, we argue the relevance of dragons for spatial planning in China. We develop a metaphorical concept-the green dragon-for grasping the condition of contemporary Chinese societies and for facilitating the development of theories and practices of spatial planning which are able to face the challenges of rapid change. We ask Chinese scholars and spatial planners to liberate Deleuzian potential for strategic spatial planning in a 'becoming-between, coming-together' of concepts which can effectively make a difference in the world. Having outlined what we regard as key transversals or diagonals between our reading of Gilles Deleuze and aspects of Chinese philosophy, we then offer the metaphor of strategic spatial planning as Chinese literati landscape painting. This is a form of painting which rejects the idea of the world being supremely organised from a particular point of view, preferring to paint immanence and transformation. Chinese literati landscape paintings, like philosophy and strategic spatial planning, 'look only at the movements'. We conclude that connections between what concepts of Chinese philosophy and those of Gilles Deleuze can do, suggest that in China, a conception of strategic spatial planning as metaphorical green dragon may offer academics and planning
\end{abstract}


practitioners a transverse way to relate the legacies of past philosophies and current thinking.

Keywords: spatial planning, Chinese literati painting, concept, transversals, dragons

\section{Introduction}

Everything is in ${ }^{1}$ transformation [...] There is no possible [stereotypical] model.

I Ching (《易经》)

The assemblages are in constant variation, are themselves constantly subject to transformations.

Deleuze and Guattari 1987: 82

The dragon represents a concentration of energy. Strongly associated with water and merging with clouds and mists, the dragon's energy is diffused through space. A dragon has no fixed form and is constantly evolving. It represents an ongoing process of transformation with the auspicious propensity to reach beyond itself. It symbolises the powers with which a form, such as a city, can be changed. A dragon symbolises efficacy, or strategy effective through variation: Deleuze and Guattari's 'pure strategy' (1987: 353) from the Chinese game of Go (weiqi, 围棋), the antithesis of rigid, mechanical practice. As Jullien (2004b: 97) suggests, 'strategic intentionality should have no fixed goal, is fixed in no particular plan, and so can adapt to every twist in the situation'.

As symbols of adaptability and transformation, together with qualities of vigilance and intelligence, dragons are relevant to spatial planning. Both in myths and paintings, Chinese dragons are depicted in a range of colours. A green dragon represents ideas of generating, growing, balancing and striving. It symbolises well-being and happiness, the new or different: 'energy renewed through change' (Jullien 1995: 153). The most auspicious placing for a green dragon is facing moving water-the archetypal smooth space of Deleuzian thinking.

The Urban Planning Society of China argues that 'urban planning is facing unprecedented challenges' which 'require a new planning system and methods' of theoretical innovation, institutional innovation and technological innovation in the production of urban or regional strategic spatial plans for a future twenty years or more. In this paper, we are inspired by the work of Gilles Deleuze and Félix Guattari to develop a concept - the green dragon - for grasping the condition of contemporary 
Chinese societies and for facilitating the development of theories and practices of spatial planning which are able to face the challenges.

Much post-structuralist theory, however, is written by Europeans and Americans, who tend to see their worlds through their 'eyes'. We suggest that it is productive to develop a Chinese form of poststructuralism, appropriate to contemporary Chinese cultural, social and economic realities. We take this further and suggest that the ideas of Deleuze and Guattari have sufficient resonances with classical Chinese philosophy to be inspirational for the development of a theory and methodology for strategic spatial planning in a spatially coextensive, fragmented, plural country. This would be a hybrid Deleuzism: 'a palimpsest of nonsynchronous, emergent, and residual formations, a mixture of various space-times, and an overlap of different modes of production' (Lu et al. 2004: 13). We adopt a metaphor of strategic spatial planning as Chinese literati landscape painting to begin to develop a theory and methodology which takes detailed steps along a broader, more flexible, longer-term path or trajectory. We conclude that resonances between Chinese philosophy and the work of Deleuze and Guattari suggest that in China, a theory of strategic spatial planning as metaphorical green dragon illustrative of immanent change may offer academics and practitioners a means to relate the legacies of past philosophies and current thinking.

We now suggest some important points of resonance which can be identified between Chinese philosophy and the work of Gilles Deleuze: change/transformation, propensities/tendencies and blandness/indeterminacy. Space constraints, however, permit us only to indicate these few connections which might hopefully inspire further research.

\section{Resonances between Chinese Philosophical Thought and Deleuzian Thinking ${ }^{2}$}

Strategic spatial planning, like Deleuze and Guattari's philosophy, should be imaginative and constructive rather than prescriptive or copy-pastes of universal concepts or ready-made 'best practice'. For Deleuze, concepts entail thinking new possibilities, creating productive connections in terms of the 'contingent circumstances and dynamics that lead to and follow from them' (Stagoll 2005: 50). Every problem or experience, then, demands practical engagement, critically thinking new concepts, unsettling or challenging traditional approaches. 
Massumi (2010: 9) points out that, for Deleuze, a concept is what it does, rather than what it is. A concept is a set of circumstances; a vector or point of application of a force moving through space (Massumi 1987: xii). Change stems from the power or force relations and the conditions of possibility which they forge. As we indicate below, the Chinese concept of shi (势) suggests force or energy of both a particular situation and the dynamic tendencies expressed through it.

For Jullien (1995: 124), Chinese reasoning 'weaves' from case to case, 'via bridges and bifurcations', as a journey of linked phases, the outcomes of which are not defined in advance, but rather unfold progressively, like a scroll. The path along which outcomes unfold does not exclude other possibilities. As one travels the journey, an experience is lived through; a landscape is sketched in.

\section{Change/Transformation}

Change or transformation has long been an important element of Chinese philosophical thinking. Epitomised, perhaps, in the I Ching (Yijing, 《易经》), philosophers and sages for over 2000 years have encouraged active participation in processes of creative transformation. It is known that Leibniz-whose work influenced Gilles Deleuze-was interested in the I Ching.

Like Deleuze and Guattari, Chinese thinkers have refrained from constructing a world of ideal forms or archetypes separate from reality. They regard reality, rather, as a 'regulated and continuous process that stems purely from the interaction of the factors in play' (Jullien 2004b: 15). Such a view of interacting elements resonates with Deleuze's account of an assemblage/agencement as 'a multiplicity which is made up of many heterogeneous terms and which establishes liaisons, relations between them [... Its] only unity is that of co-functioning' (Deleuze and Parnet 2002: 69). 'Order', in Chinese thought, is not perceived as coming from a model or strict plan, but is an immanent process, detecting those elements whose configuration is favourable to the task at hand. Chinese thought is 'a thought of processivity' (Jullien 2004b: 121), as is that of Deleuze and Guattari.

The notion of becoming (or moving beyond) is important to Chinese philosophy and also to Deleuze (see, for instance, Deleuze 1994; also Williams 2000 on becoming and architecture). For Chinese thinkers, every situation is rich with the possibility of change. There are no predetermined, rigid goals. According to Confucius's Analects (《论语》), there were four things 'from which the Master was entirely free. He had 
no foregone conclusions, no arbitrary pre-determinations, no obstinacy and no egotism' (9:4, quoted in Jullien 2000: 240). Consciousness is not fixed, but always in the process of becoming and thus open to possibility rather than being immobilised in a certain point of view. Deleuze developed an ontology of becoming, in which reality is in a continuous state of flux or differentiation. He adopted 'creative becoming as the only way to affirm the underlying real processes of differentiation or constant change behind all apparently static things' (Williams 2000: 203).

\section{Propensities/Tendencies}

For Chinese philosophers, strategy consists of two notions: a situation (xing, 形) or relation of forces, and tendencies (shi, 势) implied in the situation (Jullien 2004b). A sage can understand the forces present in a situation which constitute its tendencies. Deleuze also regards tendencies as the immanent expression of forces; a thing is 'the expression of a tendency before being the effect of a cause' (Deleuze 1999: 45). To regard issues as having determinable causes and effects, therefore, misses the importance of tendencies which cannot be captured by simple equations. Chinese sages, along with Deleuze, believe in the immanence of transformation. Strategies should develop in relation to the elements (actants) involved and their tendencies, rather than as 'copy-pastes' of 'best practice': 'Nothing could be worse than wanting to repeat what has previously led to success, for since the situation is new, so is its potential' (Sunzi, 孙子, quoted in Jullien 2004b: 177).

Jullien (1995) highlights the importance of shi as tendencies or forces generated by the disposition of a thing. As Liu (2008) explains, shi qi (势气) refers to organisational morale, min qi (民气) is public support, jing $q i$ (精气) implies economic vitality and $q i$ shi (气势) implies mental force or energy, including intentions and emotions; all of which are relevant to strategic spatial planning.

Strategy, then, exploits the propensities emanating from a particular set of force relationships in order to benefit from them. For Chinese philosophers, propensity 'provides the key to the actualisation of things' (Jullien 1995: 222). The term designates both the particular circumstances characterising different stages of a process or trajectory (perhaps major projects in spatial planning?) and the potential energy or force relations (tendency) produced. As Jullien explains, one should examine such force relations carefully as they offer information about the potential 'evolution of things' (223). Possibility is linked 
to the disposition produced in relational links between elements or actants:

If two pieces of wood are rubbed together, fire results, If fire and metal come into contact, fusion results. (Huainanzi《淮南子》, second century BC, ch. 1: 5)

In both examples in the quotation above, there is often an intercessor who manipulates the disposition. As such, this bears resonance with the idea of strategic planning practitioners 'tweaking' elements in urban assemblages: 'It is up to the general, and equally to the politician, the painter, and the writer [the strategic spatial planner?] to avail himself of the shi (势) [...] So as to exploit it to its maximum potentiality' (Jullien 1995: 260). We remind planning practitioners, however, that for Deleuze, production of the new cannot be prescribed or predicted. Neither is it inevitably beneficial and so it should not be automatically regarded as a panacea.

The key to Chinese strategy is to study the forces present, or potentially present, in a range of possible situations and to evaluate, or map, the conditions of possibility of various events taking place, by asking a series of questions, 'appreciating' the relations of force and 'assessing' the dispositions or capacities of actants (Guiguzi, 《鬼谷子》, ch. 7). The strategist should discover powerful propensities and work out how to harness, exploit or block them. 'To manage things, one must establish the potential of the situation' (ch. 5).

There are strong resonances between Chinese strategy as outlined in the Guiguzi (《鬼谷子》) and Deleuze and Guattari's pragmatics explained in A Thousand Plateaus (1987: 139-40, 146-7). If strategists trace the present, retrospectively untangling or unfolding the constituent relational conditions of possibility, they may be able to 'sense' tendencies (Deleuzian mapping), diagram the relational forces that may come into play 'either as potentialities or as effective emergences' (146) and machine a programme or strategy for what might take place. ${ }^{3}$ Strategy is concerned with implicating an effect, folding the outside in, knowing how to tackle a situation ahead of its actualisation; to 'steer it gently' (Jullien 2004b: 126) in the desired direction. Rather than following a predetermined model or template for action, good strategists adapt to circumstances which are often unforeseen and even unforeseeable. Strategy, then, aims not to predetermine an 'infinitely superior reality' (Jullien 2000: 304), but to pay attention to the tendencies which, 'given certain actions could lead to the unfolding of new ways of living' (Lorraine 2011: 3). 
The Guiguzi's (《鬼谷子》, ch. 2) advocacy of 'roundness' and 'mobility' upstream or in the longer-term future, together with 'sureness' and 'stability' downstream in the present or shorter-term future, resonate with a multiplanar theory of strategic planning (Hillier 2007; 2011), based in Deleuze and Guattari's (1987) planes of immanence and organisation. The concept of shi (势) gives us the importance of both standing back, at a distance, from something to gain an overall impression of the desired trajectory and the main lines ( $s h i$, 势) involved (see Deleuze's plane of immanence) and also of involvement with the technical detail of composition. 'Contemplating a landscape from afar, one grasps its lifelines; considering it close up, one seizes its substance' (Zong Bing, 宗炳, Hua shanshui xu, 《画山水序》, quoted in Jullien 1995: 95).

As such, thinkers in the Ming and Qing periods advised artists to outline broad structural lines, or contours, to suggest major masses, while 'wrinkles' imparted detail (Jullien 1995: 98). The overall arrangement depends on a compositional logic (vision or trajectory in spatial planning) that is seen as a source of dynamism.

Only when the painter, provoked by the very body of the landscape and the divisions through which its life pulsates, has intuitively apprehended its general movement, can the structure of the painting be planned in a more intellectual and controlled operation. (Dan Chongguang, 笪重光, quoted in Jullien 1995: 101)

Shi (势) is advanced at a stage of uncertainty, when it is barely detectable (plane of immanence), to actualise at a stage of detailed observation and measurement (plane of organisation). Resonating strongly with Deleuze and Guattari's two planes (1987; 1994), Jullien (2004b) points out that these are not two levels, but two interrelated aspects of a process.

The conjunction of the indeterminate or indirect with the more immediate, apparent in both Chinese and French-inspired poststructuralist philosophy, illuminates how desire or emotion is transformed into meaning as the two planes are joined. In Chinese poetic theory, for example, the incitatory mode is obscure, sinuous and evanescent (the plane of immanence), while the analogical mode is manifest, direct and clear (plane of organisation). As Liu Xie (刘劦思) (fifth and sixth centuries) explained, in incitatory mode, one 'suggests indirectly' in a vague manner, while one 'speaks openly', using 'categorical' references in analogical mode (quoted in Jullien 2000: 154).

Further, 'the incitatory mode consists in being moved through contact with the world, and, while the world is found there, the meaning unfolds elsewhere. [...] The theme is not exposed directly as in the direct and 
analogic modes of expression' (Luo Dajing, 罗大经, quoted in Jullien 2000: 154). The incitatory mode opens up all possible perspectives by going beyond their differences. It offers a 'complete availability of meaning' (Jullien 2000: 192) which constitutes indeterminacy or blandness, as Jullien (2004a) translates the Chinese word dan (淡) found in Chinese traditions of Confucianism, Daoism and Buddhism.

\section{Blandness/Indeterminacy}

The word dan (淡) has several meanings, including indifferent or bland and exhausted (but not tired). We can see resonances here with Deleuze's conceptualisation of exhaustion as a combinatorial of inclusive disjunctions (Deleuze 1995). Jullien (2004a) argues the positive qualities of blandness, honouring the presence of absence or the notyet identifiable. He proposes that the bland comprises an unnameable, yet potentially harmonious, combination of all values, embodying an ontology of change and difference which offers an infinite opening for expression and activity.

We advocate that long-term strategic spatial plans should be bland; the advantage of which lies in their not being tied to fixed targets and, as a consequence, they possess the capacity to be flexible. Potentiality should not be blocked by overcoded plans, but allow practitioners to summon up appropriate strategies for new situations. 'A lightly sketched affirmation does not force me to defend a position but rather allows me to evolve as I will, while remaining master of the game' (Jullien 2000: $50)$.

Blandness or obliqueness, by not setting strict spatial planning targets for around twenty to twenty-five years ahead, allows practitioners more room for manoeuvre in a long-term strategic plan which is 'enriched by its indeterminacy' (Jullien 2000: 190). The intention of such plans is not to direct detailed behaviour, but to favour adaptability in relation to circumstances.

As in Chinese landscape painting, areas of indeterminacy or 'emptiness' allow creativity and a more spontaneous reaction to changing circumstances; the opposite of over-coding and over-regulation which stifle innovation and spontaneity. Indeterminacy captures the flavour of the invisible (shen, 神) (Laozi, 《道德经》, quoted in Jullien 2004b: 113).

Our outline of resonances above suggests a network of transversals or intersecting diagonals between Chinese and Deleuzian philosophical thought. Transversals assemble multiplicities which affirm their 
differences through their connections (Bogue 2007: 2) and which generate new creative possibilities. As such, inspired by Deleuze's reading of Henri Maldiney's discussion of Hsieh Ho's (谢赫) advice to aspiring Chinese artists in the sixth century, we offer the metaphor of strategic spatial planning as Chinese literati landscape painting. This is a form of painting which rejects the idea of the world being supremely organised from a particular point of view, preferring to paint immanence and transformation.

\section{Strategic Spatial Planning as Literati Landscape Painting}

Deleuze gave a lecture on the subject of Hsieh Ho's (谢赫) advice to Chinese artists (on 27 April 1982) and published his ideas in Cinema 1: The Movement Image (1986). He was particularly impressed by Hsieh Ho's (谢赫) suggestion that the painter should first 'reflect the vital breath, that is, create movement' and then 'seek the ossature [skeleton]; that is, know how to use the brush' (Maldiney 1973: 167). The primary aim of the painter is to manifest the broad movement of the vital breath $(c h i / s h i$, 势) through the 'coming into presence' of things. But, as Hsieh Ho (谢赫) pointed out, the painter must also capture individual details in distinct brush strokes delineating the structuring articulation (infrastructure), rendering them in their 'disappearing'.

The school of literati, or scholarly, painting emerged in the eleventh to twelfth centuries in reaction to the strict conventions, regulations, minute detail (often tending to pedantry) and colour characteristic of the academic style. The literati style encompassed greater freedom of expression through varying thicknesses of brush strokes and lines of black ink on paper. Although not a typical literati art subject, broad movement and fine detail of the dragon are brilliantly depicted in Chen Rong's (陈容, 1244) work, The Nine Dragons (九龙图) (Figure 1). The concept of 'painting the eye of the dragon' refers to painting the eye in detail, often adding it last after less detailed elements have been sketched or outlined.

Deleuze sees in these processes both the two senses of exhaustion - 'the greatest exactitude and the most extreme indeterminacy' (1995: 5 )-and two means of constructing space. The first means is a broad conceptualisation of an encompassing, ambient whole within which individual elements are situated and structured. The second means is a local operation whereby an individual element is connected to a neighbouring element and then to another and so on, constructing an open space of related but heterogeneous elements. 

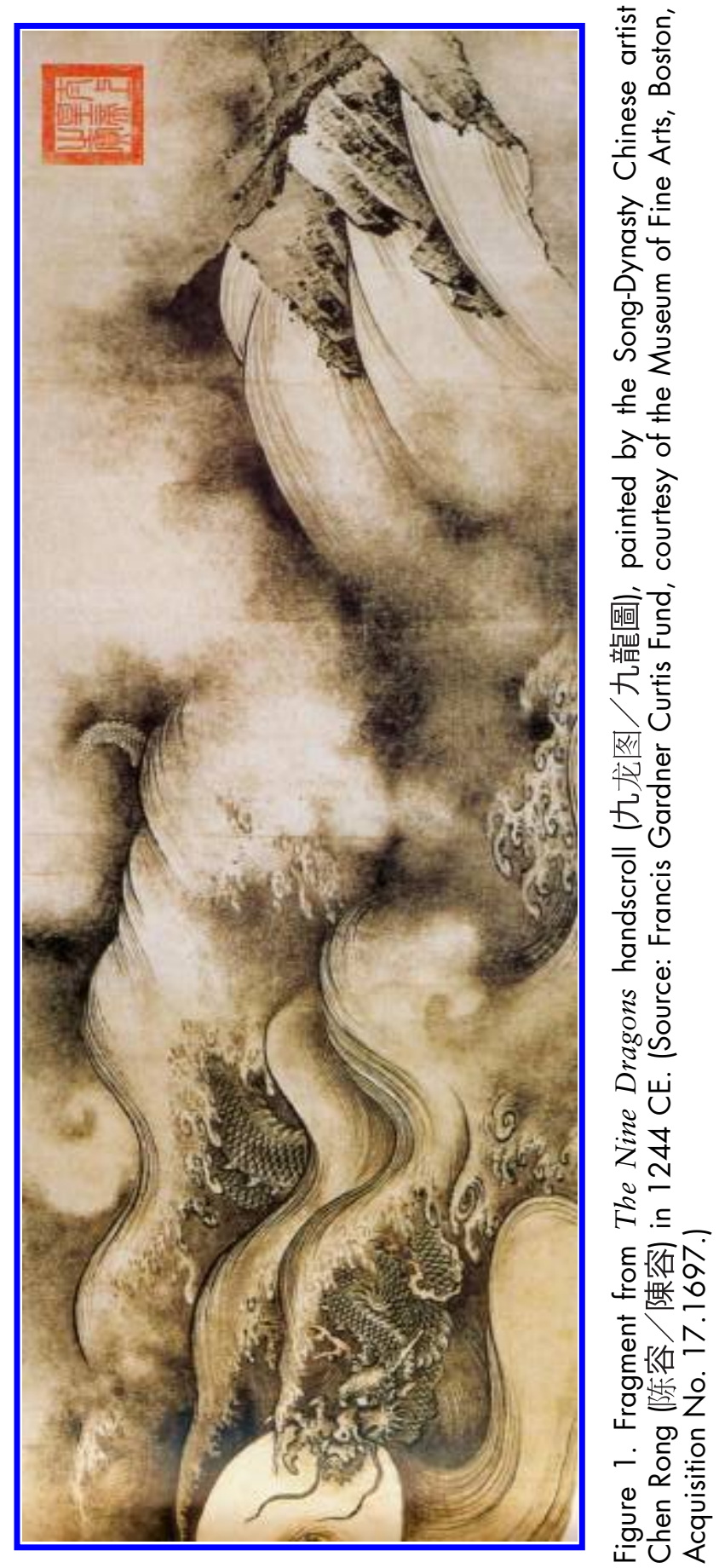
Deleuze (1982: 6; 1986: 191) refers to the broad movement of vital breath $(q i$, 气) as an 'organic spiral' in which things appear and disappear 'like the dragon concealed behind the clouds'. He was much taken with the use of lines in Chinese art, incorporating such ideas into the development of lines in his own work (see, for example, Deleuze and Guattari 1987: 497). He liked the indefiniteness of Chinese art as 'not imitative, nor structural, but cosmic' (Deleuze and Guattari 1987: 280) and the notion of the artist as someone who 'makes a becoming of the world' (Bordeleau 2009).

For Deleuze (1982), Chinese painting resonated with his concept of immanence and, by analogy, with strategic spatial planning. We suggest that the following passage from Cinema 1-Deleuze's explication of Chinese painting - can be read as a metaphor for spatial planning as a process of shaping the longer-term future of a city or region through the production of a strategic vision:

'All the art of execution is in fragmentary notations and interruptions, although the aim is to achieve a total result'. How can one paint the pike without discovering the broken line of the universe which links it to the rock it brushes in the depths of the water, and to the reeds of the bank where it lurks? But how can one paint it without animating it with the cosmic breath of which it is only a part, an impression? (Deleuze 1986: 192)

Chinese landscapes often depict mountains, in an almost infinite variety of forms, rising through clouds and mists, emerging in the distance. We offer the analogy of such 'mountains in the mist' in long-range strategic spatial planning as the visions or broad aims for a geographical area over a period of perhaps twenty to twenty-five years or longer. Mountains, as a metaphorical 'plane of immanence', function rather like 'a sieve over chaos' (Boundas 2005: 273), depicting desired conditions to work towards, such as sustainability. As Han Zhuo (韩拙) wrote in the eleventh century, 'the landscape is at once extraordinarily entrancing and subtle-evanescent' (quoted in Jullien 2009: 36) and for Wu Daozi (吴道子, eighth century), 'even though, from the perspective of the brush, it is not complete, the sense-intentionality is complete' (quoted in Jullien 2009: 71).

In the foreground, elements in the painting are more concrete and individuated. Like Deleuze's 'plane of organisation', the artist is concerned with the development of identifiable forms. We offer the analogy for strategic spatial planning of local area plans, design briefs and detailed major projects, all of which tend to be relatively local 
or micro-scale, shorter term and content specific. They facilitate small movements or changes along the dynamic, open trajectories of the plane of immanence or longer-term strategic plan.

Between the indistinct distance and the elements visible in the foreground, 'a narrow path takes shape' (Jullien 2009: 56). 'Between', here, implies opening a thing wide from the inside and allowing passage through it (95). 'Between' indicates the inseparability of the concrete, tangible foreground form and the more vague, bland, 'spirit dimension' (xing-shen, 形-神) of mountains or longer-term desires. As the tenthcentury commentator Jing Hao (荆浩) explains, the artist must take care not to get bogged down in form, but keep everything in flight or movement. Jing Hao (坪浩), however, also reminds us that the artist cannot transmit the spirit dimension without resorting to tangible form. The artist, therefore, works between the two planes of spirit dimension and tangible form; not dominated by either, but open to both simultaneously.

Guo Xi (郭熙, eleventh century) wrote that artists must consider landscapes from a distance 'to grasp the lines of force' and must look at the close up 'to grasp their materiality' (Jullien 2009: 146).

'Directly before us, the ravines and the mountains, the woods and the forests curve and tangle together. Through that arrangement, the landscape comes to us; we do not tire of its details and our eyes are satisfied in their quest near at hand. From an angle, the far plane that deploys the mountain chains without interruption fades away. We do not tire of that remoteness and our

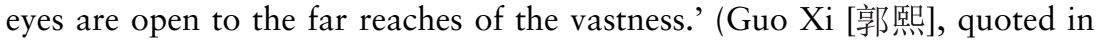
Jullien 2009: 156; original emphasis)

Resonance is strong here with Deleuze's suggestion of 'a turbulent, stormy zone where particular points and the relations of forces between these points are tossed about' above the 'solidified [...] visual dust' (Deleuze 1988: 121). Practitioners (whether artists or strategic spatial planners) need to engage creatively with this throbbing, pulsating graphic, to 'tear open the firmament itself, to let in a bit of free and windy chaos and to frame in a sudden light a vision that appears through the rent' (Deleuze and Guattari 1994: 203).

Chinese theorists construct 'a system of variance serving as a framework for difference' (Jullien 2009: 151). Resonant with Deleuze's (1994) ontology of difference, the constitutive being of a mountain, for example, is its potentiality. Form (xing, 形) is both a noun and a verb. It implies transformation; something in transformation. Painting 
thus involves selection of form from a range of different possibilities, as does strategic spatial planning. Both are marked by a choice 'concerning the real' in the principle of its production (Jullien 2009: 205).

Chinese landscape paintings often contain depictions of mountains and water, especially oceans. In fact, as Jullien (2009: 121-2) points out, the term for landscape is shan-shui (山-水, mountain-water). Water exemplifies Deleuzian smooth space; seemingly undifferentiated, infinite, irregular, dynamic. Artists regard landscape elements as being in dynamic interaction. Each element of the painted landscape (or strategic plan) exists in relation to the others: 'each element is relational, constitutively and intrinsically' (188). Mountains and water are not regarded as properties, but as capacities (137) to which the artist gives vitality, just as spatial planners may attempt to give vitality to city centres, residential estates, and so on through plans and design guides.

Mountains and water are, in Jullien's (2009: 181) words, 'proposed' to the painting, not as proper forms, but as resources for exploration and exploitation. Plans may designate zones of land use in similar manner. If designation is too narrow, in either painting or planning, vision becomes limited and obstructs the interactions between actants and elements which give rise to beneficial transformation. Artists and planners need some rules, however. For Fang Xun (方薰, eighteenth century), 'wherever there is diligence, there are always rules' (quoted in Jullien 2009: 192) and for Deleuze, we require 'just a little order to protect us from chaos' (Deleuze and Guattari 1994: 201).

Literati painting, from the Song Dynasty onwards, paints 'intentionality' or potentiality. As Zhang Yanyuan (张彦远, ninth century) suggested, the 'formal resemblance that the painting has in view lies entirely in the brush's motion structuring forms' (quoted in Jullien 2009: 222), which is itself grounded in potentiality. A landscape painting (or a plan) is an image 'not of reality reified into a form, but of the momentum that brings it about' (230). It expresses an aspiration; a propensity.

Rather than describing and representing, the painting seeks to incite flows of energy (shi, 势). Rather than fixing qualities, the painting suggests capacities and potentialities. Shi Tao (石涛, seventeenth century) summarises the purpose of painting as 'the great rule of modification assuring the world's continuance' (quoted in Jullien 2009: 233). We propose that the purpose of strategic spatial planning could be summarised similarly. 


\section{Conclusion: Painting Deleuzian Dragons}

Rather than reveal, Chinese philosophy (and literati painting) aims to indicate. Scholars or sages advise that the deep meaning of a text should unfold gradually rather than be rigidly predetermined. In this paper, we have attempted to identify several resonances between Chinese philosophical and French-inspired post-structuralist thinking. Established connections between the I Ching (《易经》), Leibniz and Deleuze suggest that China, as Saussy proposes, could be 'the land where [Deleuzian] poststructuralism can come into its own' (2001: 178).

Following the Chinese year of the Water Dragon, we offer the metaphor for strategic spatial planning of Chinese literati painting which rejected the idea of the world being supremely organised from a particular point of view, preferring to paint immanence and transformation. Literati painting allows glimpses through mists and clouds of what might actualise, yet affords freedom for our understanding to evolve and change as we regard the work on different occasions or from different angles. Literati painting also depicts some foreground elements in detail. This is its inherent realism. Transformational vitality is then provided by 'painting the dragon's eye' of local detail.

Finally, we argue that the potential for change in Chinese strategic spatial planning comes from within, rather than copy-paste application of authors such as Gilles Deleuze and Félix Guattari. Western sources are part of the frame; but only a part. Chinese scholars and planning practitioners should 'break it open' as Massumi (2010: 13) advocates, in order to 'liberate the pure form of its potential' in processes of 'becoming-between, coming-together'.

\section{Notes}

1. We thank Paul Patton and an anonymous referee for suggestions which have strengthened the paper. A different version of the paper with a spatial planning (rather than a Deleuzian) emphasis has been previously published in Chinese as 绘制青龙: 面向中国战略空间规划的后结构主义理论与方法论, Urban Planning International, 25:5, pp. 88-95 (2010).

2. Hillier, as a non-Mandarin reader, has relied on work by François Jullien, as quoted, for her very generalised understanding of Chinese philosophical thought.

3. See Hillier's $(2010 ; 2011)$ methodology of strategic navigation for similar concept in strategic spatial planning. 


\section{References}

Bogue, Ronald (2007) Deleuze's Way, Aldershot: Ashgate.

Bordeleau, Erik (2009) 'La Chine et la ligne. Une étude de la référence chinoise dans Mille Plateaux', in Dalie Giroux, René Lemieux and Pierre-Luc Chénier (eds), Contr'hommage pour Gilles Deleuze, Québec: Les Presses de l'Université Laval, pp. 45-61.

Boundas, Constantin V. (2005) 'The Art of Begetting Monsters: The Unnatural Nuptials of Deleuze and Kant', in Stephen H. Daniel (ed.), Current Continental Theory and Modern Philosophy, Evanston, IL: Northwestern University Press, pp. 254-79.

Deleuze, Gilles (1982) 'Lecture 16, 27/04/1982', La voix de Gilles Deleuze en ligne, available at http://www.univ-paris8.fr/deleuze/article.php3?id_article=167 (accessed 29 January 2010).

Deleuze, Gilles (1986) Cinema 1: The Movement Image, trans. Hugh Tomlinson and Barbara Habberjam, London: Continuum.

Deleuze, Gilles (1988) Foucault, trans. Seán Hand, London: Athlone Press.

Deleuze, Gilles (1994) Difference and Repetition, trans. Paul Patton, London: Athlone Press.

Deleuze, Gilles (1995) 'The Exhausted', trans. Anthony Uhlmann, SubStance, 24:3, pp. 3-28.

Deleuze, Gilles (1999) 'Bergson's Conception of Difference', trans. Melissa McMahon, in John Mullarkey (ed.), The New Bergson, Manchester: Manchester University Press, pp. 43-65.

Deleuze, Gilles and Félix Guattari (1987) A Thousand Plateaus: Capitalism and Schizophrenia, trans. Brian Massumi, London: Athlone Press.

Deleuze, Gilles and Félix Guattari (1994) What Is Philosophy?, trans. Hugh Tomlinson and Graham Burchell, London: Verso.

Deleuze, Gilles and Claire Parnet (2002) Dialogues II, trans. Hugh Tomlinson and Barbara Habberjam, New York: Continuum.

Hillier, Jean (2007) Stretching beyond the Horizon: A Multiplanar Theory of Spatial Planning and Governance, Aldershot: Ashgate.

Hillier, Jean (2010) 'Strategic Navigation in an Ocean of Theoretical and Practice Complexity', 战略性引导的方法在复杂规划理论与实践中的运用, Urban Planning International, 25:5, pp. 44-59. In Mandarin.

Hillier, Jean (2011) 'Strategic Navigation across Multiple Planes: Towards a Deleuzean-inspired Methodology for Strategic Spatial Planning', Town Planning Review, 82:5, pp. 503-27.

Jullien, François ([1992] 1995) The Propensity of Things, trans. Janet Lloyd, New York: Zone Books.

Jullien, François ([1995] 2000) Detour and Access, trans. Sophie Hawkes, New York: Zone Books.

Jullien, François ([1991] 2004a) In Praise of Blandness: Proceeding from Chinese Thought and Aesthetics, trans. Paula M. Varsano, New York: Zone Books.

Jullien, François ([1996] 2004b) A Treatise on Efficacy, trans. Janet Lloyd, Honolulu: University of Hawai'i Press.

Jullien, François ([2003] 2009) The Great Image Has No Form, or on the Nonobject through Painting, trans. Jane Marie Todd, Chicago: University of Chicago Press.

Liu, Yu-Ming (2008) 'Naturalistic Chi(Qi)-based Philosophy as a Foundation of Chi(Qi) Theory of Communication’, 明清自然气本论:作为气的传播 / 沟通理论的哲学基础, China Media Research, 4:3, pp. 83-91, available at http://www.chinamediaresearch.net (accessed 28 April 2013). 
Lorraine, Tamsin (2011) Deleuze and Guattari's Immanent Ethics, Albany, NY: SUNY Press.

Lu, Guang-Xiang, Yang, Zhi-Feng and He, Meng-Chang (2004) 'Urban Space Characteristics of Self-organizing of Xiamen', 厦门市城市空间结构分布的自组织特征, Journal of Beijing Normal University (Natural Science), 40:6, pp. 825-30.

Maldiney, Henri (1973) Regard, parole, espace, Lausanne : L'Age d'Homme.

Massumi Brian (1987) 'Translator's Foreword: Pleasures of Philosophy', in Gilles Deleuze and Félix Guattari, A Thousand Plateaus: Capitalism and Schizophrenia, trans. Brian Massumi, London: Athlone Press, pp. ix-xix.

Massumi, Brian (2010) 'What Concepts Do: Preface to the Chinese Translation of $A$ Thousand Plateaus', Deleuze Studies, 4:1, pp. 1-15.

Saussy, Haun (2001) Great Walls of Discourse and Other Adventures in Cultural China, Cambridge, MA: Harvard University Press.

Stagoll, Cliff (2005) 'Concepts', in Adrian Parr (ed.), The Deleuze Dictionary, Edinburgh: Edinburgh University Press, pp. 50-2.

Sunzi, (1993) [5-6 вСE] Sun Tzu: The Art of Warfare, trans. and ed. Roger T. Ames, New York: Ballantine Books.

Williams, James (2000) 'Deleuze's Ontology and Creativity: Becoming in Architecture', Pli, 9, pp. 200-19, available at http://www.warwick.ac.uk/ philosophy/pli_journal/pdfs/williams_pli_9.pdf (accessed 4 January 2010). 